\title{
End the Lockdown for Animals - Reflecting and Campaigning on Three Key Arenas of Human-Animal Interaction Linked to Zoonotic Diseases
}

How ending the wildlife trade, cage-keeping, and fur farming can prevent another global health crisis, rooted in the exploitation of animals.

\section{Martina Pluda}

MA Animal Law and Society, PhD candidate in Animal Law, Autonomous University of Barcelona

Director for Italy of Humane Society International - Europe, Trieste, Italy

Cita recomendada PLUDA, M., End the Lockdown for Animals - Reflecting and Campaigning on Three Key Arenas of Human-Animal Interaction Linked to Zoonotic Diseases, dA. Derecho Animal (Forum of Animal Law Studies) 11/4 (2020). - DOI https://doi.org/10.5565/rev/da.543

\begin{abstract}
Covid-19, SARS, MERS, Ebola, avian influenza: Wake-up calls for humanity to reassess our relationship with animals and the natural world. $73 \%$ of emerging infectious diseases in humans are zoonotic, originating in animals. Together, zoonoses account for billions of illnesses and millions of deaths across the globe. Their spread has direct connections to our use and misuse of animals, trapped, traded, bred, raised, confined, transported in ways that pose a serious risk for the development of zoonotic pathogens with the potential to infect human populations. In order to prevent future pandemics, three key animal protection issues must be tackled: the trade of live wild animals; the intensive confinement of animals farmed for food; fur farming and the fur trade.
\end{abstract}

Keywords: Pandemics; zoonotic diseases; wildlife trade; factory farming; cage-keeping; fur trade.

Resumen - Poner fin al encierro para los animales - Una reflexión e una iniciativa sobre tres escenarios clave de interacción entre humanos y animales relacionados a enfermedades zoonóticas

El Covid-19, el SARS, el MERS, el Ébola, la influenza aviar: llamadas de atención a la humanidad para reevaluar nuestra relación con los animales y el mundo natural. El 73\% de las enfermedades infecciosas emergentes en humanos son zoonóticas y se originan en animales. Juntas, las zoonosis representan miles de millones de enfermedades y millones de muertes en todo el mundo. Su propagación tiene conexiones directas con nuestro uso y mal uso de los animales, atrapados, comercializados, criados, confinados, transportados de formas que representan un riesgo grave para el desarrollo de patógenos zoonóticos con el potencial de infectar poblaciones humanas. Para prevenir futuras pandemias, se deben abordar tres cuestiones clave de protección animal: el comercio de animales silvestres vivos; el confinamiento intensivo de animales criados para la alimentación; las granjas peleteras y el comercio de pieles.

Palabras clave: Pandemias; enfermedades zoonóticas; comercio de vida silvestre; cría intensiva; mantenimiento de jaulas; comercio de pieles. 
The current global health crisis has clearly highlighted the link between the way humans use and abuse animals and our health. The COVID-19 pandemic is a wake-up call for humanity to reassess our relationship with animals. When zoonotic diseases spill over from animals to people, human activity is frequently the cause - whether in the form of our intensive confinement of farm animals, our destruction of natural habitats, the poaching of wild animals or the multibillion-dollar international wildlife trade (the likely source of this disease).

Like COVID-19, some $73 \%$ of emerging infectious diseases in humans are zoonotic, which means they originate in animals. ${ }^{1}$ In addition, more than $58 \%$ of known infectious diseases affecting humans, like the rabies virus and Salmonella, are transmitted by animals. ${ }^{2}$ Together, zoonotic diseases account for billions of infections and millions of deaths across the globe and their spread has direct connections to the way we raise, confine, trade, commodify, and use animals, turning them into ticking bombs. The areas in which humans interfere with the natural world and animals are multiple, creating situations that favor the development and spread of zoonotic diseases. Time and again we witness human health emergencies that can be traced back to how human beings use animals in commerce, whether for agricultural production, the wildlife trade, animal testing or the pet industry, highlighting the dire need for policy changes.

In addition, pandemics have an enormous impact on domestic and global economies regardless of where they originate. COVID-19 was preceded by SARS and MERS, which were coronaviruses of similar origins that had the potential to become global crises, yet the policy shifts that would have served to prevent future issues were not made in their wake. The International Monetary Fund has stated that the current pandemic could be far worse than the Great Depression and projects the global economy will contract by $3 \%$ in 2020 , which will create lasting impacts. ${ }^{3}$

COVID-19, SARS, MERS, Ebola, avian influenza, swine flu, mad cow disease: these should all have been wake-up calls for humanity to reassess our relationship with animals, connections that should rise to the forefront of public policy discussions in the immediate future. The COVID-19 pandemic has forced governments across the globe to impose severe restrictions that have had and will continue to have massive economic costs and a myriad of other consequences. But there has been less discussion about identifying and modifying the human behaviors and institutions that contribute to the emergence of zoonotic diseases, and the role of public policy that, in light of what we know about pandemic threats, would enhance human safety. The COVID-19 pandemic underscores the urgency of critical policy shifts and strong action at the intersection of animal protection and public health, within both domestic and international contexts.

For this reason Humane Society International - Europe (HSI/Europe) calls on the European Commission and Member State governments to implement some crucial measures to prevent another global health crisis, rooted in the exploitation of animals, and to shape a compassionate, safe and free future for all - humans and animals. The actual areas of risk are many, from factory farming and wildlife markets to puppy mills and stray animal management. Nevertheless HSI/Europe's efforts focus on the three that in this time of crisis have been exposed as flawed and dangerous, playing a major role in the spread of the virus. The purpose of the proposed actions is to tackle three areas that see animals confined, perpetually "locked down" and exposed to the risk of viral infections. These are:

1. The trade of live wild animals;

2. The intensive confinement of animals farmed for food;

3. Fur farming and the fur trade.

\section{Stopping the trade of live wild animals}

In 2018 the EU imported over 560,000 live, wild, CITES-listed mammals, birds, reptiles and amphibians. Whether captive-bred or wild-caught, wild animals bought and sold for the exotic pet trade, as exotic food or for other commercial purposes can transmit a variety of viral, bacterial, fungal, and parasitic infections that pose serious health risks to humans. The list of pathogens that can be transmitted via wild animals is very long: hantaviruses, Bartonella, Tularemia, Herpes B virus, Mycobacterium, ringworm, Yersinia, Clostridium, Campylobacter, Leptospira, Trichinella and a variety of other bacterial, parasitic, and

\footnotetext{
${ }^{1}$ KARESH WB, COOK RA, BENNETT EL, NEWCOMB J. Wildlife trade and global disease emergence. Emerg Infect Dis. 11/7 (2005) 1000-1002. DOI:10.3201/eid1107.050194.

${ }^{2}$ WOOLHOUSE MEJ, GOWTAGE-SEQUERIA S. Host range and emerging and reemerging pathogens. Emerg Infect Dis. 11/12 (2005)1842-1847. DOI:10.3201/eid1112.050997.

${ }^{3}$ IMF. World Economic Outlook, April 2020: The Great Lockdown. Retrieved from:

https://www.imf.org/en/Publications/WEO/Issues/2020/04/14/weo-april-2020.
} 
fungal agents. ${ }^{4}$

In the years since the first outbreak of SARS, one team of researchers after another has warned that controlling or stopping the sale of wild animals, particularly in crowded markets, was key to preventing another SARS-like outbreak. For example, the authors of a 2007 study of SARS concluded that the presence of a large reservoir of SARS-CoV-like viruses in animals like horseshoe bats, together with the culture of eating exotic mammals in southern China, is a time bomb. They stated that the possibility of the re-emergence of SARS and other novel viruses from animals and therefore the need for preparedness should not be ignored. ${ }^{5}$ Today, as COVID-19 continues to spread around the world, the consequences of ignoring such warnings have become plain to see. Also, if SARS, COVID-19 and other zoonoses, and the warnings that epidemiologists have been issuing for years have taught us anything, it should be that the existence of wildlife markets in their current form - particularly the large, unhygienic, mixed-species markets associated with both SARS and COVID-19 - is a serious threat to human health on a global scale.

There is scientific consensus that the novel COVID-19 coronavirus originated in bats, was likely passed on to an intermediate host species through that animal's ingestion of bat feces, and subsequently jumped to humans through contact with that animal. Scientists also concur that the spread of the COVID-19 virus from this intermediate animal to humans most likely occurred in a wildlife market in Wuhan, China, that sold live wild animals for human consumption. ${ }^{6}$ Demonizing any given species involved in transmission of disease is not the answer. But examining the origin of COVID-19 is necessary to preventing future pandemics, and that origin requires that we rethink our exploitation of wildlife.

In live wildlife markets, animals are kept in cramped, stressful, and unsanitary conditions and are sold and often slaughtered on site in inhumane fashion for human consumption. The suffering of animals in these markets is extensive. Bodily fluids such as saliva, blood and feces may be present on surfaces and packaging that humans touch. This intermingling of fluids has a clear connection to disease transmission, and these unsanitary conditions are a risk to vendors and consumers alike. Human, animal, and ecosystem health are inextricably linked, and the well-being of one will inevitably impact another.

Humane Society International/Europe supports banning all trade, transport, and consumption of wildlife, and recommends that governments around the world take immediate action to close wildlife markets within their borders. This ban should also apply to import, export and internal transport of live wildlife or wildlife meat intended for sale in wildlife markets. Closing wildlife markets is not the only action that needs to be taken to prevent another zoonotic disease from developing into a global pandemic. Therefore, banning the trade of live wild animals altogether, including all imports to the European Union, is essential to protect people from zoonoses. There is already a good precedent for this. In 2007, the European Union banned the import of wild birds as a measure to prevent the spread of avian influenza, which not only can devastate poultry populations, but can also affect human health.

\section{Ending intensive confinement of animals farmed for food}

Intensive animal production involves thousands of animals of a similar genotype being raised for meat, dairy, or egg production in confined housing systems at a single location with a rapid population turnover. Keeping farm animals like this is a risk factor facilitating the development of zoonotic pathogens, such as avian and swine flu, which have the potential to infect human populations. ${ }^{7}$ Despite these risks, farm animals are still predominantly kept by the thousands in close confinement at large-scale, industrial agriculture operations (also known as "factory farms").

Farmed animals, with which humans have greater contact than with wildlife, may act as the source for important pandemic viruses and when thousands of animals are tightly confined, it creates a larger "laboratory" in which potential pathogens can exchange genetic material and generate viral forms. There is in fact evidence that these pathogens can become more virulent when they circulate through large groups of closely confined animals. ${ }^{8}$ A 2013 review published in the Proceedings of the National Academy of Sciences

\footnotetext{
${ }^{4}$ RILEY PY, CHOMEL BB. Hedgehog zoonoses. Emerg Infect Dis. 11/1 (2005) 1-5. DOI: 10.3201/eid1101.040752.

${ }^{5}$ CHENG VCC, LAU SKP, WOO PCY, KWOK YY. Severe acute respiratory syndrome coronavirus as an agent of emerging and reemerging infection. Clin Microbiol Rev. 20/4 (2007) 660-694. DOI:10.1128/CMR.00023-07.

${ }^{6}$ MACKENZIE JS, SMITH DW. COVID-19: a novel zoonotic disease caused by a coronavirus from China: what we know and what we don't. Microbiol Aus (2020). DOI: 10.1071/MA20013.

${ }^{7}$ LEIBLER JH, OTTE J, ROLAND-HOLST D. Industrial food animal production and global health risks: exploring the ecosystems and economics of avian influenza. EcoHealth, 6 (2009) 58-70. DOI: 10.1007/s10393-009-0226-0.

${ }^{8}$ DHINGRA MS, ARTOIS J, DELLICOUR S, LEMEY P, DAUPHIN G, VON DOBSCHUETZ S, VAN BOECKEL TP, CASTELLAN DM, MORZARIA S, GILBERT M. Geographical and historical patterns in the emergences of novel highly pathogenic avian influenza (HPAI) H5 and H7 viruses in poultry. Front in Vet. Sci. (2018). DOI: 10.3389/fvets.2018.00084.
} 
found "strong evidence" that "intensified farming systems can be linked to disease emergence and amplification." 9

Historically, these operations have been hosts to deadly zoonoses with the ability to cause pandemics. Highly pathogenic avian influenza and swine flu - the latter of which spread to 30 countries in 2009 by humanto-human transmission - are serious concerns. Certain strains of avian influenza have a $60 \%$ mortality rate, and the World Health Organization cautions that if a highly infectious form of this virus were to develop, it could spark the next global pandemic. ${ }^{10}$ This is particularly concerning as avian influenza outbreaks are ongoing across Europe. A new report from the European Food Safety Authority rates the likelihood of the virus spreading from wild birds to poultry as high. ${ }^{11}$ Eliminating the intensive confinement of farm animals would reduce the risk of generating new diseases with the potential to spread to people.

Considering that more animals are crowded together in the same building when they are tightly confined in cages and crates, providing a greater number of potential pathogen hosts, governments around the world should phase-out the cage confinement of egg-laying chickens, mother pigs in gestation crates, and calves in veal crates. In addition to disease risk, factory farms do not provide an acceptable level of animal welfare. Even though some of the most egregious forms of animal confinement have been eliminated in the European Union, to this day 300 million animals, such as hens and sows, still spend their lives, or a substantial part of it, in confinement. Additionally, while billions from the EU budget are spent on agricultural funding, the EU should ensure that Common Agricultural Policy funds are used to support the transition to extensive, higherwelfare cage-free systems. Governments should also take steps to ensure that public institutions implement procurement guidelines that exclude cruel practices such as confinement. In the private sector, food companies should also complete their pledged animal welfare commitments, including eliminating their purchasing and sale of raw materials that come from operations that confine animals in cages and crates.

In addition to moving away from intensive animal confinement systems, there is an increasingly recognized need for closer scrutiny of our food system and its reliance on animal protein. The Corona outbreaks amongst slaughterhouse workers is the United States, Canada, Germany, and other countries, as well as the recent detection of a new flu virus in pigs that could possibly cause a future flu pandemic, are signals that our current food system is deeply flawed. Governments and the private sector must play a larger role in the shift to more plant-based proteins to ensure a greater availability of diverse, dependable, and healthy protein sources. Plant-based options include no animal-derived ingredients and do not carry the same environmental, public health, or animal welfare threats associated with factory farming. The food industry should also play a greater role in promoting public health and animal welfare by investing in plant-based innovations, offering more plant-based menu options, and making more grocery shelf space for plant-based proteins. Whether because they see how profitable plant-based meat can be or because they understand the importance of diversifying. Multiple animal meat companies have already either invested in other companies' plant-based meats or developed their own line of animal meat alternatives.

Governments and the private sector also have an opportunity to help fund technology that has the potential to transform the food system: animal meat grown outside of animals. In the long term, cultivated meat and other food innovations (e.g. fungi-based alternatives) can offer a more ethical and safe solution to our dependence on farm animals. Research programs exist in some countries and should be prioritized in others to develop technologies that ensure a greater availability of more diverse, safe, and dependable protein sources. Government funding in the Netherlands for research on cultivated meat began in 2005, and several universities have hosted research fellows in their laboratories to help develop cultivated meat. Similarly, cultivated meat companies throughout the world have received investments from the private sector to develop the necessary technology. ${ }^{12}$ But more private investment and government funding of research programs is crucial to speed the development and economic scalability and viability of these technologies as an alternative to factory farming.

Only by reducing the number of animals in intensive confinement systems and shifting away from

\footnotetext{
${ }^{9}$ JONES BA, GRACE D, KOCK R, ALONSO S, RUSHTON J, SAID MY, MCKEEVER D, MUTUA F, YOUNG J, MCDERMOTT J, PFEIFFER DU. Zoonosis emergence linked to agricultural intensification and environmental change. PNAS, 110/21 (2013) 83998404. DOI: $10.1073 /$ pnas.1208059110.

${ }^{10}$ WHO. H5N1 influenza. Retrieved from: http://www.who.int/foodsafety/areas_work/zoonose/avian/en/index1.html.

${ }^{11}$ EFSA. Avian influenza: Virus Spreading Rapidly in Europe. Retrieved from: https://www.efsa.europa.eu/en/news/avian-influenzavirus-spreading-rapidly-

europe?ml_subscriber $=1560715640661087601 \&$ ml_subscriber_hash $=$ z7q6\&utm_source=newsletter\&utm_medium=email\&utm_ca mpaign=linfluenza_aviaria_minaccia_leuropa_la_cina_blocca_limport\&utm_term=2020-11-23.

${ }^{12}$ BusinessWire. Global Synthetic (Cultured) Meat Technologies and Markets, 2019 Report - 2021-2022 Estimates \& Projections to 2027. Retrieved from: https://www.businesswire.com/news/home/20190219005414/en/Global-Synthetic-Cultured-Meat-TechnologiesMarkets-2019.
} 
reliance on factory farm-raised animal protein can we reduce the risk of another public health crisis. Without addressing the inherent risks in factory farming, the next global pandemic can easily arise from within our own food system.

\section{Banning fur farming and the fur trade}

Every year, around 100 million animals around the world are raised and killed for their fur. Over 95\% of fur sold globally comes from farmed wild animals such as mink, foxes, raccoon dogs, rabbits, and chinchillas. China is the world's largest producer of fur products and these species are common sights also at live animal markets in China. These animals, which are undomesticated, are kept in intensive confinement systems where they spend their entire lives in cramped battery cages, deprived of the ability to exhibit natural behaviors such as digging, hunting for food, living in family groups and, for mink, accessing swimming water, and exposed to the risk of viral infections, before being killed for a frivolous and anachronistic product.

Foxes and raccoon dogs were in fact found to have been infected with SARS and mink with COVID19. These last cases precisely in European countries such as Denmark, France, Greece, Italy, Lithuania, Poland, Spain, Sweden, the Netherlands. SARS-CoV-2 was in fact first identified on two mink farms in the Netherlands on 26 April 2020. This was followed by the infection of two fur farm workers and outbreaks on other farms. According to a statement of the Dutch Minister of Agriculture it was "extremely likely" that the two workers had contracted COVID-19 from the animals. ${ }^{13}$ On 3 June 2020, a final report was published confirming the culling of the animals on the infected farms, a measure taken "in the interests of both public and animal health." ${ }^{14}$ In Denmark, over 280 out of the 1,139 fur farms has been infected with COVID-19 and health authorities reported 12 human cases of COVID-19 caused by a specific mink-associated variant strain of the SARS-CoV-2 virus. Millions of mink had to be killed as a result. What prompted the Danish Prime Minister to take this science-led step were mutations in the SARS-CoV-2 virus from its mink hosts which could compromise the effectiveness of any vaccine. ${ }^{15}$

A Dutch research team, which investigated the initial outbreaks on 16 Dutch mink farms (with a total of around 720,000 animals) using whole genome sequencing found that 66 of $97(67 \%)$ people living or working on these farms had evidence of SARS-CoV-2 infection. Genetic analysis showed that the mutated variants of SARS-CoV-2 virus were the same as those found in mink and were not identical to those found in unrelated SARS-CoV-2 patients living in proximity of the farms. ${ }^{16}$

The World Organisation for Animal Health (OIE) has called on countries "to protect animal health and welfare, and consequently public health" and advised that actions should be taken to "Monitor susceptible animals, such as mink [...], as well as humans in close contact with them. Active monitoring is recommended as it might be difficult to detect early infections, especially [in] mink". ${ }^{17}$ In addition, the risk assessment recently published by the European Centre for Disease Prevention and Control proposed a number of measures, including the monitoring and surveillance of mink farms (repetitive surveys and/or testing of dead mink on weekly basis). ${ }^{18}$

The fur trade presents clear human health and animal welfare risks. Fur farming and trade is also a failing industry. Designers and retailers - including Gucci, Prada, Versace, Burberry, Macy's, Bloomingdale's, YOOX Net-a-Porter, Farfetch, and Michael Kors - have all committed to stop using fur, opting instead for alternatives that are better for animals and the environment. Fur auction houses have reported reduced sales, lower prices for pelts and financial difficulties.

Given that mink, foxes and raccoon dogs can become infected with SARS-CoV-related coronaviruses, the production and trade in these species should be banned globally and apparel companies should reinforce the trend toward fur-free fashion to eliminate the demand for animal fur altogether. Fur farming has been prohibited and/or is in the process of being phased-out in many EU Member States such as Austria, the Czech

\footnotetext{
13 KREVER M. Dutch authorities believe minks may have infected human with Covid-19. CNN. Retrieved from: https://edition.cnn.com/world/live-news/coronavirus-pandemic-05-20-20intl/h_a41e960bbcbd8f2b9f8b9201c153b5bc?fbclid=IwAR3wjxAFzBdq09xQW-cUNXrOvJtMEOnJzCmO01VRIxWNzmq7dqNnWwR9yc.

${ }^{14}$ Government of the Netherlands. Advice regarding OMT-Z on minks and SARS-CoV-2. Retrieved from: https://www.government.nl/documents/letters/2020/06/03/advice-regarding-omt-z-on-minks-and-sars-cov-2.

${ }^{15}$ Reuters Staff. Denmark plans to cull its mink population after coronavirus mutation spreads to humans. Reuters. Retrieved from: https://www.reuters.com/article/us-health-coronavirus-denmark-mink-idUSKBN27K1X6.

${ }^{16}$ OUDE MUNNINK BB et al. Jumping back and forth: anthropozoonotic and zoonotic transmission of SARS-CoV-2 on mink farms. bioRxiv (2020). DOI: 10.1101/2020.09.01.277152.

17 OIE. Statement on COVID-19 and mink. Retrieved from: https://www.oie.int/en/for-the-media/press-releases/detail/article/oiestatement-on-covid-19-and-mink/.

${ }^{18}$ European Centre for Disease Prevention and Control. Detection of new SARS-CoV-2 variants related to mink - 12 November 2020. Retrieved from: https://www.ecdc.europa.eu/en/publications-data/detection-new-sars-cov-2-variants-mink.
} 
Republic, Croatia, Slovenia, the Netherlands, Luxembourg, Slovakia, and Belgium. Ireland, Bulgaria, and Lithuania are also presently considering bans on fur farming.

\section{Conclusion}

COVID-19 has demonstrated just how far-reaching and devastating the consequences of a pandemic can be. Just as COVID-19 has affected nearly every facet of life, so could a future pandemic, including one with dramatically higher mortality rates. Therefore, it is critical that the European Union and national governments make key policy changes to help prevent future disease outbreaks. With most emerging infectious diseases that infect humans originating in animals, it is crucial that industries change their interactions with and treatment of animals now. Policymakers play a central role in ensuring reforms are made. Since zoonotic diseases have already been the cause of millions of human deaths across the world and could be the source of many more, it is imperative that lawmakers take immediate action. Whether it is trading wild animals or intensively confining farm and fur animals, scientists have identified and warned us about the activities that promote disease spread and could lead to future pandemics. The COVID-19 crisis is a reminder that we must not only examine the use of animals in various arenas, but that we should use this knowledge to create meaningful change.

Humane Society International - Europe has long championed science-based public policy measures in all instances where the treatment of animals and the interests and demands of public health converge. Nowhere is this more important than in the case of pandemic disease, and in such exigent circumstances an action agenda targeting key areas of risk and danger is vital to the safety and well-being of everyone. Scrutiny and reform of the three above-mentioned key arenas of human-animal interactions could hardly be more timely or imperative. 